\title{
NEGASI SEMANTIK DALAM POLA PEMAKNAAN BAHASA BEBERAPA KELOMPOK ISLAM DI INDONESIA
}

\author{
Muhammad War'i \\ Sekolah Tinggi Ilmu Tarbiyah (STIT) Darussalimin NW Praya \\ akmaly.warok@gmail.com
}

\begin{abstract}
This paper elaborates on the meaning of words religious-based by several Muslim groups in Indonesia. The study used a qualitative approach with interpretive descriptive analysis. Using the language philosophy analysis, the result of this research is the meaning constructions of words religius based in several Muslim groups in Indonesia experiences semantic negation. This means that there is a partial meaning of religiously oriented words. The semantic negation is caused by several factors, namely, the weakness of some groups' in understanding of linguistic concepts, the existence of a textuall mindset (bayani) that makes them fixated on the text, and the inheritance of concepts inherited from their predecessors. As a reflection of the description made, it is necessary to present a more pluralistic language meaning pattern involving semantic, pragmatic and speech contexts. When each group is able to understand language in a plural way, then efforts to build dialogue in the context of diversity of religions and beliefs will be well implemented. The attitude of accepting openly the concept of other groups in interpreting their religious terms will present a tolerant and peaceful religious life.
\end{abstract}

Keywords: Semantic Negation, Language Meaning, Philosophy of Language

\begin{abstract}
Abstrak
Tulisan ini mengelaborasi tentang pemaknaan kata berbasis keagamaan oleh beberapa kelompok muslim di Indonesia. Penelitian menggunakan pendekatan kualitaif dengan analisis deskriptif interpretatif. Dengan menggunakan pisau analisis filsafat bahasa, penelitian berkesmipulan bahwa konstruksi pemaknaan bahasa berorientasi keagamaan beberapa kelompok muslim di Indonesia mengalami negasi semantik. Artinya ada pemaknaan secara parsial terhadap kata-kata yang berorientasi keagamaan. Negasi semantik tersebut disebabkan oleh beberapa faktor, yaitu, lemahnya pemahaman beberapa kelompok tersebut terhadap konsep linguistik, adanya pola pikir bayani yang membuat mereka terpaku pada teks, serta adanya sakaralisasi konsep yang diwariskan dari para pendahulu mereka. Sebagai refleksi dari uraian yang dibuat, maka perlu dihadirkan pola pemaknaan bahasa yang lebih pluralistik dengan melibatkan aspek semantik, pragmatik serta konteks tuturan. Ketika setiap kelompok mampu memhami bahasa secara plural, maka upaya membangun dialog dalam konteks keragaman agama maupun keyakinan akan bisa dilaksanakan dengan baik. Adanya sikap menerima dengan terbuka konsep kelompok lain dalam memaknai istilah-istilah keagamaannya akan menghadirkan kehidupan beragama yang toleran dan damai.
\end{abstract}

Kata kunci: Negasi Semantik, Pemaknaan Bahasa, Filsafat Bahasa 


\section{Pendahuluan}

Makna yang diberikan oleh seseorang atau suatu kelompok terhadap suatu kata dapat berbeda dengan makna yang diberikan oleh orang atau kelompok lain terhadap kata yang sama. Demikian juga pemahaman terhadap suatu kata atau istilah yang terdapat dalam kitab suci al-Quran dan hadis bisa jadi dipahami secara berbeda di kalangan umat Islam. Istilah-istilah yang ada dalam agama Islam tampaknya tidak dimaknai secara seragam oleh berbagai kelompok muslim di berbagai belahan dunia. Upaya untuk memahami secara lebih tepat mengenai makna suatu istilah sebagaimana dipahami oleh kelompok lain, dapat membantu upaya menumbuhkan toleransi di berbagai kelompok yang ada dalam masyarakat.

Dalam hal ini dapat dikemukakan contoh kata atau istilah jihad yang tercantum dalam kitab suci al-Quran dan hadis. ${ }^{1}$ Sebagian kelompokmuslim memaknai kata jihad sebagai perang di jalan Allah. Kamus Besar Bahasa Indonesia (KBBI), misalnya, mengartikan kata 'berjihad' sebagai "berperang (di jalan Allah); berjuang". Sedangkan sebagian aktivis muslim yang lain memahami makna kata jihad tidak hanya sebagai berperang di jalan Allah, tapi juga mencakup kegiatan-kegiatan lain yang

\footnotetext{
${ }^{1}$ Kata jihad (جهَاد) tercantum, antara lain, pada Q.S. Mumtahanah (60): 1, al-Furqan (25): 52, al-Hajj (22): 78, dan al-Taubah (9): 24
}

mengandung kebaikan dan kemaslahatan bagi sesama umat manusia. Kalau kata 'berjihad' dimaknai sebagai "berperang (di jalan Allah) atau berjuang", dalam Kamus Besar bahasa Indonesia itu juga tercantum makna kata jihad dengan tiga makna, yaitu: “(1) usaha dengan segala daya upaya untuk mencapai kebaikan; (2) usaha sungguhsungguh membela agama Islam dengan mengorbankan harta benda, jiwa, dan raga; (3) perang suci melawan orang kafir untuk mempertahankan agama Islam. ${ }^{2}$

Selain kata 'jihad', dalam perbendaharaan kosakata keagamaan juga terdapat sejumlah istilah lain yang tidak jarang dipahami secara berbeda oleh berbagai kelompok muslim, seperti istilah kafir, bid'ah, khurafat, khilafah, dan sebagainya. Pemaknaan kata bid'ah dan khurafat bisa jadi berbeda di kalangan warga Muhammadiyah dan Nahdhatul Ulama, atau di kalangan warga Persatuan Islam (Persis). Terkadang muncul pertikaian di tengahtengah masyarakat dikarenakan perbedaan dalam memaknai sebuah kata atau sebuah istilah yang terdapat dalam teks kitab suci al-Quran dan hadis itu.

Sebagai negara penuh keragaman, bangsa Indonesia merupakan negara yang rawan konflik, apakah itu berbentuk konflik budaya, agama, politik dan sebagainya.

\footnotetext{
2 Tim Penyusun Kamus Pusat Pembinaan dan Pengembangan Bahasa, Kamus Besar Bahasa Indonesia, (Jakarta: Balai Pustaka, 1995), hlm. 414.
} 
Salah satu persoalan yang dewasa ini masih banyak muncul di negara ini adalah persoalan kelompok-kelompok dalam Islam yang sering kali terlibat konflik karena perbedaan pemaknaan terhadap suatu teks berupa ayat ataupun hadits.Misalnya makna bid'ah dalam sebuah hadits nabi.Beberapa kelompok memiliki pemaknaan bahwa bid'ah adalah perbuatan yang tidak pernah dilakukan oleh nabi dan dilakukan oleh manusia saat ini.Seperti amalan-amalan dzikiran untuk orang yang meninggal dunia, yang tidak berasal dari Rasulullah, ritual keagamaan dan lainnya.Salah satu contoh kongkritnya adalah Maulid.

Disisi lain beberapa kelompok memaknakan bid'ah berbeda, mereka melihat bahwa bid'ah itu dibagi dua yaitu hasanah dan dholalah. Artinya tidak semua perbutan yang tidak pernah dilakukan oleh nabi merupakan perbuatan bid'ah dalam arti yang menyimpang. Kelompok yang berpadangan seperti ini tetap melakukan ritual maulid sebagai kegiatan rutin di kelompok mereka karena memandang ritual tersebut tidak termasuk bid'ah yang buruk.

Contoh diatas menjadi bukti bahwa terjadi keragaman pemaknaan kata bahasa Arab oleh kelompok-kelompok muslim yang ada di Indonesia. yaitu dari sisi medan makna, atau makna yang terkandung dalam suatu kata. Jika dilihat lebih jauh, pemaknaan kata pada kelompok-kelompok tersebut dipengaruhi oleh latar ideologi, budaya dan geneologi pendiri kelompok terkait.

Sering kali terdengar tentang kelompok-kelompok yang begitu gampang memvonis salah satu tradisi adat di negara ini sebagai perbuatan khurafat dan bid'ah yang karenanya harus dibasmi dan dimusnahkan.Tidak jarang pemaknaan yang seperti itu berlanjut ke konflik sosial yang semakin keras bahkan cendrung berdarah. Kasus di Sampang,Madura adalah salah satu contohnya dimana kerusuhan terjadi karena pemaknaan yang sepihak tentang Syiah tanpa mengkonfirmasi kepada kelompok yang berkaitan. Demikian pula kasus-kasus kekerasan antar kelompok beragama lainnya yang terjadi di negeri ini.

Masih segar dalam ingatan beberapa waktu lalu, dimana beberapa kelompok muslim saling beradu argumentasi perihal hasil Musyawarah Nasional (Munas) NU yang dianggap menciderai tuntunan agama. NU dianggap tidak wajar ketika meniadakan istilah kafir bagi kaum non-muslim. Segera kemudian menjadi viral di media masa seputar pernyataan tersebut. Jika mendengar keterangan secara komprehensif, sejatinya perbedaan argumentasi beberapa kelompok muslim yang berseberangan tersebut bisa dimediasi melalui pengkajian secara menyeluruh dan keterbukaan komunikasi untuk saling memahami.

Berangkat dari fenomena berbahasa tersebut, penelitian ini akan mengkajipola 
pemaknaan bahasa Arab kelompok-kelompok muslim khususnya yang ada di Indonesia dalam konteksbahasa berorientasi keagamaan. Identifikasi pola semantika bahasa ini menjadi penting ketika dikorelasikan ke arah penggunaannya dalam aktivitas komunikasi secara sosiologis antar kelompok yang ada. Menurut peneliti sangat penting untuk dilakukan peninjuan semacam ini karena sering kali pemaknaan istilah-istilah keagamaan berimplikasi terhadap menyalahkan, menyesatkan atau mengkafirkan kelompok lainnya yang sering kali berdampak kepada konflik sosialkeagamaan.

Mengingat kajian dalam penelitian ini memiliki titik tekan terhadap medan makna, maka pisau analisis yang digunakan adalah beberapa konsep dalam kajian filsafat bahasa, sepertisalah satunya, language games. Teori yang dicetuskan oleh Ludwig Wittgenstein memiliki tataran tehnis identifikasi makna yang lebih luas, Ditegaskan dalam teori ini bahwa makna suatu kata bukan pada makan secara tektual (what the mean 'apa artinya?') tetapi pada bagaimana kata itu digunakan (how to use?). Beberapa konsep filosofis seputar teori bahasa yang sejalan dengan konsep 'permainan bahasa', juga akan digunakan dalam pisau analisisnantinya.

Hal yang ingin dituju dengan menggunakan konsep filsafat bahasa dalam kajian ini adalah upaya mengidentifikasi paradigma berbahasa yang ada dalam beberapa kelompok keagamaan di Indonesia dengan berprinsip pada permainan bahasa. Nantinya analisis ini akan menghasilkan peta konsep pemaknaan berbahasa (referensi semantik) kelompok-kelompok tersebut. Hasil pemetaan itu kemudian menjadi data penting dalam melihat pengaruh pardigma berbahasaterhadap pemaknaan istilah-istilah keagamaan.

Berdasarkan penelusuran peneliti mengenai kasus-kasus tersebut, banyak dari konflik yang terjadi merupakan imbas dari pemaknaan istilah-istilah agama yang cenderung dilakukan secara kaku dan tekstual dan kemudian mengklaim kebenaran atas apa yang difatwakan tersebut. Kenyataan ini tentu berbanding terbalik dengan prinsip keragaman yang ada di Indonesia, karena jika melihat konteks keindonesiaan maka diperlukan pemaknaan teks yang lebih menyesuaikan keadaan dari pada tekstualisme yang buta.

Penelitian ini ingin mengelaborasi tentang bagaimana pemaknaan kata-kata berorientasi keagamaan di kalangan kelompok muslim di Indonesia. Berbeda dengan kajian tafsir, penelitian ini lebih kepada kajian filsafat bahasa, yaitu penggunaan istilah-istilah keagamaan oleh anggota kelompok muslim Indonesia serta implikasi epistemologisnya terhadap kajian-kajian keislaman berupa hukum fiqh, tafsir, dan lain sebagainya. 
Penelitian ini urgen dilakukan, baik dengan alasan teoritis maupun praktisnya. Secara teoritis, penelitian akan memberikan kontribusi terhadap pengembangan keilmuan bahasa dalam upaya melihat faktor bahasa sebagai struktur sosial dan keagamaan yang sangat berpotensi mengarah paradigma ideologis seseorang. Dengan kata lain pendekatan bahasa secara teoritis akan membantu dalam pengkajian keislaman yang lebih beragam dan memposisikan bahasa sebagai faktor penting di dalamnya.

Di samping itu penelitian ini akan meramaikan kajian-kajian Islam berparadigma integrasi-interkoneksi yaitu antara bidang kajian keagamaan dan kebahasaan (linguistik). Hubungan-hubungan antara ritual agama dan tradisi ataupun paradigma berbahasa terhadap pemahaman seseorang sejatinya harus memiliki porsi yang pantas mengingat peran vital bahasa dalam mengkonstruksi identitas dan pemahaman seseorang.

Secara aplikatif, kajian ini akan mengalternasi komunikasi dialogis antar kelompok islam yang ada untuk memahami kerangka paradigma berbahasa sehingga memahami epistemologi yang digunakan dalam memaknakan kata tertentu dalam hal eksistensi kelompok maupun tentang pengamalan ritual keagamaan. Sebagaimana dikemukakan di atas, upaya untuk memahami secara lebih tepat mengenai makna suatu istilah sebagaimana dipahami oleh kelompok lain, dapat membantu upaya menumbuhkan toleransi di berbagai kelompok yang ada dalam masyarakat. Dengan demikian, upaya untuk memahami istilahistilah agama sebagaimana dipahami oleh berbagai kelompok dalam umat Islam, dapat membantu upaya meningkatkan toleransi dan komunikasi yang lebih baik di antara berbagai elemen dalam masyarakat Islam.

Di samping itu, penelitian semacam ini juga diperlukan untuk memberikan alternatif model pemaknaan istilah-istilah agama yang lebih kontestual dan penyadaran berbahasa bagi orang-orang yang akan memaknai istilah atau kata-kata yang terdapat pada kitab suci al-Quran dan hadis. Dengan demikian, dapat diharapkan munculnya pandangan yang lebih luas dalam pemaknaan kata-kata yang terdapat pada kitab suci al-Quran dan hadis, sehingga pesan ayat-ayat suci tidak cenderung direduksi oleh kepentingan kelompok dikarenakan kelemahan pemahaman seseorang atau kelompok tentang makna bahasa atau makna suatu kata.

Sebelumnya, penelitian tentang kelompok-kelompok muslim di Indonesia sejatinya merupakan objek kajian yang sudah banyak dilakukan, hanya saja penelitian yang menggunakan perspektif filsafat bahasa masih sangat minim, padahal kajian kebahasaan ini sangat penting guna membuka cakrawala pemaknaan bahasa. Di 
antara penelitian yang terkait dalam hal ini adalah penelitian-penelitian tentang beberapa kelompok radikal yang dilakukan oleh beberapa peneliti diantaranya: Syafii Anwar. Tentang "Faktor Pemicu Tumbuhnya Radikalisme" yang dimotori oleh Jaringan Islam Liberal ${ }^{3}$. Dalam penelitian tersebut ditemukan bahwa tumbuhnya radikalisme di Indonesia dipengaruhi oleh fatwa MUI yang cendrung menjastifikasi.

Demikian pula apa yang ditulis oleh Abdurrahman Mas'ud tentang "Pengaruh Radikalisme Kanan Terhadap Bangsa Dan Negara,"4 dia berkesimpulan bahwa kelompok radikalisme tidak terlalu mengancam kesatuan negara Indonesia. Namun demikian, keberadaannya sering kali memicu konflik internal masyarakat. Di samping itu, penelitian juga dilakukan oleh Sakti Wira Yudha, dengan judul "Radikalisme Kelompok Islam." Dalam temuannya Yudha berkesimpulan bahwa kelompok-kelompok Islam di Indonesia memiliki pengaruh politik yang sangat kuat, yang mana hal tersebut juga dipengaruhi oleh media $\operatorname{massa}^{5}$.

\footnotetext{
${ }^{3}$ Syafi'i Anwar. Faktor Pemicu Tumbuhnya Radikalisme. (Jakarta: Jaringan Islam Liberal, 2013) dalam situs www.islamlib.com akses tanggal 10 April 2015

${ }^{4}$ Abdurrahman Masud. Pengaruh Radikalisme Kanan terhadap Bangsa dan Negara. (Puslitbang Pendidikan Agama dan Keagamaan Badan Litbang dan Diklat Kementerian Agama, 2010) dalam situs www.kemenag.go.id akses tanggal 10 April 2015

${ }^{5}$ Sakti Wira Yudha. Radikalisme Kelompok Islam, Tesis. (Jakarta: Universitas Indonesia, 2010) hlm. 7-20
}

Berbeda dengan penelitian penelitian tersebut, penelitian ini sebagaimana dipaparkan di muka lebih menitikberatkan kepada kajian filsafat bahasa, yakni melihat fenomena berbahasa untuk medapatkan suatu gambaran utuh dalam menganalisis kehidupan beragama di Indonesia terkhusus pada model pemaknaan mereka atas istilahistilah agama.Dari uraian tersebut, dapat diajukan beberapa pertanyaan, yaitu: bagaimana kelompok muslim mengkonstruksi makna kata berbasis keagamaan secara semantik?, dan faktor apa yang mempengaruhi konstruksi semantika berbahasa kelompok muslim di Indonesia? oleh karena itu, penelitian bertujuan untuk mengetahui konstruksi makna kata berbasis keagamaan secara semantika bahasa, serta mengetahui faktor yang mempengaruhi konstruksi pemaknaan berbahasa kelompok muslim di Indonesia.

Diakhir pembahasan akan ditambahkan dengan refleksi filosofis dari konsep pemaknaan bahasa yang diungkap penelitian ini. Refleksi tersebut kemudian digunakan dalam mengalternasi model pemahaman bahasa yang lebih berimbang. Dalam arti bahwa sebuah kata harus dipahami tidak secara parsial tetapi secara kompleks dan berimbang. Tambahan pula, diharapkan dari pemahaman yang mendalam dan menyeluruh tentang sebuah konsep akan melahirkan sikap inklusif dalam melihat perbedaan. Ketika sikap 
inklusif ini tumbuh dalam diri seseorang maka akan terwujud kehidupan beragama yang harmonis.

\section{Kerangka Konseptual}

\section{Kompleksitas bahasa Arab}

Sebagai alat komunikasi, bahasa memiliki aspek yang yang sangat kompleks. Terdapat banyak kajian seputar objek bahasa dalam korelasinya dengan bidang lain. Bahsa dalam konteks sosiologisnya mendapat perhatian khusus melalui kajian sosiolinguistik. Kemudian bahasa dalam hubungan psikologis penuturnya mendapat perhatian melalui bidangn Psikolinguistik. Serta berbagai kajian-kajian keilmuan yang sudah sangat banyak menjadi perhatian para pengkaji. Adapun tulisan ini, akan mengkaji seputar pola filosofis dari konsep berbahasa beberapa kelompok muslim.

Secara sederhana, penelitian ini akan mengkaji referensi semantik setiap penutur yang terlibat dalam objek yang dimaksud. Bahasa-bahasa yang berbau keagamaan dijadikan objek kajian untuk memetekan pola paradigma berbahasa kelompok-kelompok yang dimaksud. Mengingat bahasa keagamaan yang dimaksud dalam tulisan ini adalah bahasa Arab, maka perlu ditegaskan dalam kerangka konseptual ini perihal makna objek disini.

Merupakan hal yang sudah lumrah, bahwa bahasa Arab merupakan bahasa yang memiliki keistimewaan yang sangat besar baik secara teologis maupun secara ilmiah. Secara teologis dibuktikan dengan terdapat banyak ayat al-Quran ataupun hadits Nabi Muhammad SAW yang menyinggung tentang posisi vital bahasa Arab. Dan secara ilmiah, keistimewaan bahasa Arab terlihat dari luasnya kajian bahasa Arab, baik secara linguistik mikro maupun makro. Secara mikro bahasa Arab dikenal sebagai bahasa yang paling kaya kosa-katanya. Demikian pula dengan konsep kaidah kebahasaannya yang cendrung rumit dibandingkan dengan bahasa-bahasa lain di dunia. Sedangkan secara makro, bahasa Arab memiliki hubungan yang sangat kompleks dengan tradisi penuturnya terutama dalam kaitannya dengan agama Islam.

Sebagai bahasa operasional dalam agama Islam, bahasa Arab tentunya memiliki sisi teologis yang tidak bisa dihindari, namun demikian, dalam kajian ini peneliti akan menghadirkan beberapa bahasa berorientasi keagamaan yang banyak menjadi diskursus kaum muslimin, seperti kata kafir, jihad, bid'ah, ulama. Berbagai isitlah yang berorientasi keagamaan tersebut seringkali hadir dalam berbagai referensi semantik tradisi berbahasa kaum muslimin di Indonesia. Dan sering kali pemahaman kelompok-kelompok muslim tentang istilahistilah tersebut melahirkan pendirian sikap kelompok tertentu secara ideologis. 


\section{Ruang semantik dalam filsafat bahasa}

Dalam penelitian ini, objek formal yang digunakan adalah filsafat bahasa, terutama konsep permainan bahasa 'language games' yang dicetuskan oleh Ludwig Wittgenstein. Language games merupakan suatu konsep filsafat bahasa yang memiliki prinsip kolektifitas berbahasa. Artinya proses berbahasa merupakan suatu proses pemaknaan yang menyeluruh, sehingga tidak cukup dilakukan hanya dengan mencari makna secara gramatikanya saja. $^{6}$ Dalam pandangan Wittgenstein (periode yang kedua), bahasa akan mendapatkan maknanya ketika dituturkan oleh penutur, dan tuturan itu sendiri akan memperoleh maknanya ketika berada dalam suatu komunitas dengan konteks tertentu. Dalam suatu aktivitas pemaknaan bahasa atau dalam hal ini teks, peran penutur, pendengar dan situasi menjadi hal yang niscaya.

Terkait dengan kajian dalam penelitian ini, konsep filsafat bahasa language games diposisikan sebagai suatu model pemaknaan, dimana tugas penting dari seorang pemberi makna teks (bahasa berorientasi keagamaan) harus memiliki model permainan ini. Kenapa demikian? Karena secara kultural, Indonesia memiliki keragaman yang luar biasa, yang karenanya

\footnotetext{
6 Ludwig Witgenstein. Philosophical investigation. (London: Great Britanian, 1986) hlm. 30 .
}

pemaknaan konsep agama harus sesuai dengan situasi yang berkembang di dalamnya.

Konsep filsafat bahasa dianggap yang relevan dan cocok untuk menganalisis fenomena yang tengah berkembang di negeri ini. Namun demikian, secara konseptual teori Language games-nya Wittgenstein masih cukup general untuk menjadi pisau analisis yang mendalam, maka dari itu peneliti juga melihat beberapa teori pendukung lainnya yang secara substansi sama namun lebih terperinci. Misalnya saja komentar Fodor tentang teori-teori filsafat analitikanya Wittgenstein, dia memberikan masukan yang cukup penting dalam kajian pada penelitian ini. Dia mengatakan, "kepercayaan dan semantika penafsiran mempengaruhi hasil pembacaan teks."7

Salah satu bagian penting yang juga menjadi alasan peneliti menggunakan teori tersebut dalam penelitian ini adalah keinginan untuk membentuk suatu pendekatan keagamaan yang berobjek formal filsafat bahasa sehingga pemaknaan istilahistilah agama itu memiliki landasan kebahasaan yang secara teknis tidak melulu tentang penutur dan pendengar, tapi juga bagian penting lainnya berupa konteks. Wittgenstein lebih jauh tentang language games membeberkan kegelisahan intelek-

\footnotetext{
${ }^{7}$ Meredith Wiliams. Witgenstein, Mind and Meaning Towards a Social Conseption of Mind (London: Routledge, 1999), hlm. 101.
} 
tualnya dalam bukunya Philosophical Investigation tentang paradoks penafsiran (paradoks of interpretation). Baginya banyak sekali fenomena berbahasa manusia yang memiliki paradoksi seperti satu kata yang sama, tapi memiliki makna yang berbeda ketika dalam penggunaannya. Misalnya saja dalam dua pernyataan berikut: "dia memilih untuk berdamai dalam pertengkaran itu." dan "dia berdamai dengan polisi ketika ditilang di jalanan.” Kata berdamai pada dua pernyataan di atas tentulah satu kata namun memiliki makna yang berbeda ketika digunakan pada situasi yang berbeda.

Dalam konteks keagamaan, hal yang sama juga dapat ditemukan, misalnya dalam penggunaan istilah pemimpin, dalam masyarakat Arab, ada banyak istilah untuk kata menyebutkan pemimpin, seperti: khalifah, amir, imam, wali, rois dan sebagainya. Kata-kata yang banyak tersebut di Indonesia digunakan oleh beberapa kelompok keagamaan di negeri ini secara beragam.HTI misalnya, untuk pemimpin tertinggi menggunakan istilah amir, $^{8}$ kemudian NU menggunakan istilah Rois ' $A m,{ }^{9}$ dan adapun dalam kelompok-kelompok sufi, pemimpin diistilahkan dengan wali, murobbi. ${ }^{10}$

\footnotetext{
${ }^{8}$ Taqiyuddin Annabhani. Struktur Negara Khilafah. Terj. (Jakarta: HTI Press, 2010) hlm. 15

${ }^{9}$ www.nu.or.id akses tanggal 18 April 2015

${ }^{10}$ Wawancara dengan Muhammad Anshori, seorang anggota Tariqat Hizb Nahdlatul Wathan. Wawancara dilakukan pada tanggal 9 April 2010
}

Di samping itu, amir juga digunakan oleh Majelis Mujahidin Indonesia (MMI) untuk pemimpin tertinggi mereka. Dalam job dies, tugas masing-masing kelompok itu berbeda-beda menurut pandangan masingmasing. Dalam organisasi HTI misalnya, amir itu menduduki posisi tertinggi yang mana hal tersebut menutut dia harus menguasai ilmu-berilmu agama dan yang terpenting dia harus memiliki pemahaman dan pengalaman politik yang bagus.Adapun amir dalam MMI, sosok pemimpin lebih digambarkan sebagai seorang yang faqih secara syariah.

Ada lagi contoh lain dari language games ini, kata "kiri" misalnya, dalam tugas seorang sopir angkot, hal tersebut dimaknai sebagai permintaan penumpang untuk turun dari angkutan kota. Sementara itu dalam hal politik, kiri dimaknai sebagai golongan yang memiliki ideologi komunis sosialis. Adapaun dalam kajian pemikiran islam, kata kiri memiliki arti kelompok yang cendrung liberal.

Pada prinspinya, penggunaan istilahistilah tersebut merupakan fenomena berbahasa yang dipengaruhi oleh beberapa hal, misalnya ideologi atau warisan historis suatu kelompok.Celakanya perbedaan penggunaan istilah tersebut sering kali diruncingkan sebagai hal yang substantif dan berujung konflik, apakah itu berbentuk konflik argumentatif maupun konflik real secara tindakan. Model penggunaan bahasa 
ini dipengaruhi oleh pemaknaan bahasa yang di dalamnya terjadi proses negosiasi ideologis. Artinya, penggunaan istilah tersebut difaktori oleh keyakinan kelompok tersebut tentang istilah-istilah yang terkait secara syar'i yang dibuktikan dengan dalildali agama dari penegasan al-Quran maupun Hadits.

Kepada pisau analisis kita pada penelitian ini, Filsafat bahasa memberikan alternatif model pemaknaan bahasa yang menyeluruh, berupa teks, penutur, dan konteks. Mengingat pentingnya tiga komponen tersebut, maka menghadirkan bahasa dalam sebuah permainan bahasa sangat perlu untuk dilakukan. Hal ini mengingat setiap bidang kehidupan memiliki tata aturan permainannya sendiri. Tanpa aturan, permainan tidak akan pernah bisa berlangsung. Penerapan teori ini dalam penelitian tentang pemaknaan bahasa berorientasi keagamaan bertujuan untuk memberikan model pemaknaan yang lebih plural. Sebagaimana komentar Lyotard, bahwa teori Language gamesnya Wittgenstein merupakan teori yang sangat menekankan aspek paradigmatik sehingga konsep tersebut dibandang cukup plural. ${ }^{11}$

Dari uraian diatas, dapat dilihat bahwa filsafat bahasa memiliki ruang semantik yang sangat luas. Hal ini terlihat dari komitmen filsafat bahasa dalam melihat sebuah tuturan, dari konsep Wittgenstein

\footnotetext{
11 Rizal Mustansir. Filsafat Analitik (Yogyakarta: Pustaka Pelajar, 2007) hlm.113
}

nampak bahwa bahasa harus dipahami secara kompleks. Demikian pula beberapa konsep yang relevan tentang bahasa seperti pemahaman bahasa Charles S. Pierce yang menekankan pemahaman bahasa secara pluralistik. ${ }^{12}$ Melalui konsepnya "pragmatic pluralism" Pierce memberikan komponen yang lebih rinci dari konsep language games.Perpaduan berbagai konsep filsafat bahasa yang kemudian menjadi kerangka teoritis penelitian ini akan melahirkan suatu analisis yang diharapkan mampu memberikan alternatif pemaknaan bahasa yang lebih pluralistik.

\section{Metode Penelitian}

Penelitian ini merupakan penelitian kualitatif desktiptif interpretatif. Penelitian ini memiliki tujuan untuk mengelaborasi pola pemahaman bahasa terutama aspek semantiknya. Mengingat penelitian ini merupakan analisis filsafat bahasa, maka untuk penentuan objek riset digunakan pendekatan google trend. Pendekatan ini sangat mengandalkan papan penelusuran google. Artinya, proses analisis ini menekankan dialektika yang berkembang di media massa seperti Facebook terutama dalam kolom komentarnya. Selain itu situs-situs yang memuat beberapa artikel seputar istilahistilah keagamaan yang mejadi objek penelitian ini seperti: kata kafir, bid'ah, ulama

12 SandraB. Rosenthal. Charles Peirce's Pragmatic Pluralism. (New York: State University of New York Press, 1994), hlm. 41 
dan lain sebagainya. Oleh karena itu, pemetaan kelompok yang dimaksud dalam penelitian ini adalah akun-akun yang mengkonstruksi makna kata-kata tersebut dalam artikel yang mereka tulis.

Dari pemaparan mereka tentang konsep-konsep yang menjadi objek dalam penelitian ini, akan dilakukan analisis kebahasaan secara filosofis. Dengan demikian peneliti tidak akan melihat lebih jauh tentang dalil-dalil teologis yang banyak digunakan sebagai rujukan oleh kelompokkelompok yang ada, tetapi lebih pada penekanan konsep inti berupa ruang semantikanya. dalam arti bahwa kesimpulan setiap artikel akan memperlihatkan sempit atau tidaknya ruang semantik yang digunakan.

Data dalam penelitian ini akandiolah sejak kegiatan pengumpulan data dilakukan. Huberman dan Miles mengatakan bahwa proses analisis terdiri dari tiga sub-proses yang saling terkait, reduksi data, penyajian data dan penarikan kesimpulan atau verifikasi. ${ }^{13}$ Analisis data dilakukan melalui tahapan berikut.Pertama, mencatat semua temuan fenomena di lapangan baik melalui pengamatan, wawancara maupun dokumentasi dalam bentuk catatan literal. Peneliti akan membuat catatan pengamatan selama melakukan observasi. Kedua, menelaah

13 A. Michael Huberman dan Mattew B. Milles, 'Manajememen Data dan Metode Analisis', dalam Norman K . Denzim dan Yvonna S. Lincoln, Handbook of Qualitative Research, Terj. Darisyanto dkk.(Jogyakarta: Pustaka Pelajar, 2009), hlm. 592 kembali hasil pengamatan dan dokumentasi serta memisahkan data yang penting dan data yang tidak penting.Pekerjaan ini diulang kembali untuk memeriksa kemungkinan kekeliruan klasifikasi. Ketiga, mendeskripsikan data yang telah diklarifikasi, untuk kepentingan penelaahan lebih lanjut dengan memperhatikan fokus dan tujuan penelitian.Keempat, membuat analisis akhir untuk laporan penelitian.

\section{Pembahasan}

\section{Konstruksi Semantik Kata-kata Berbasis}

\section{Keagamaan}

Diantara beberapa kata-kata Arab berbasis keagamaan yang banyak dijumpai adalah kafir, bid'ah, jihad, ulama'. Penulis akan menghadirkan beberapa kata tersebut dengan mengacu pada pemahaman beberapa kelompok yang dijaring melalui penelusuran di internet. Dimulai dari kata kafir. Secara etimologis, kafir memiliki asosiasi maknainkar, tidak taat.Sedangkan secara terminologis kafir diasosiasikan dengan pengingkaran terhadap ajaran nabi Muhammad. Kata kafir kemudian melahirkan bentuk isim fail,kaafir yang diasosiakan dengan orang-orang yang tidak mempercayai ajaran-ajaran teologi dalam Islam.

Terminologi kafir beberapa waktu yang lalu mencuat menjadi perdebatan publik melalui hasil Musyawarah Nasional Nahdlatul Ulama, salah satu organisasi terbesar di Indonesia. Pada acara tersebut 
diantara kesimpulannya adalah meniadakan kata kafir dalam konteks bernegara dan diganti dengan istilah muwatinun (warga negara $)^{14}$. Argumentasi tersebut segera menjadi perdebatan publik. Ada yang mendukung dan ada pula yang menolak. Beberapa kelompok yang mendukung melihat bahwa pemaknaan kata kafir memang perlu diredifinisi dalam konteks bernegara. ${ }^{15}$ Hal tersebut untuk membangun kontruksi sosial kenegaraan yang toleran dan damai. Namun demikian beberapa kelompok yang tidak sepakat dengan hasil Munas tersebut mengatakan bahwa menolak kata kafir merupakan bentuk menentang ayat-ayat Tuhan yang sudah banyak menggunakan istilah kafir.

Diantara argumentasi yang dilemparkan adalah perihal penggantian kata kafir dalam al-Quran, "apakah ayat dalam surat Alkafirun 'qul ya ayuhal kafirun' diganti dengan 'ayyuhal non muslim' gitu?’ demikian pula pernyataan lainnya yang bernada sama, "jangan engkau mengolokolok Allah dan Rasul-Nya dengan mencoba merevisi Alquran. Sungguh kalian sudah kafir." Serta berbagai komentar serupa yang bisa ditemukan di media massa Facebook. Bisa disimpulkan bahwa kelompok pertama

\footnotetext{
14 Tempo.co. NU Usul Sebutan Kafir ke Nonmuslim Indonesia Dihapus, via. https://nasional.tempo.co/read/1181081/. Akses tanggal 2 mei 2019

${ }^{15}$ Nu.or.id. Munas NU, Kafir, dan Hiruk Pikuk di Media Sosial, via. http://www.nu.or.id/post/read/103253/ akses tanggal 5 Mei 2019
}

melihat kata kafir dalam pandangan yang lebih luas, sementara pendapat kedua melihat kafir dalam konteks yang lebih sempit, yakni dalam konteks teologi semata.

Selain kata kafir, terdapat kata bid'ah yang sebelumnya sudah lebih sering menuai perdebatan. Diantara argumentasi yang mengikat perdebatan beberapa kelompok muslim tentang kata bid'ah adalah tentang amalan-amalan yang termasuk bid'ah. Terdapat perbedaan pendapat yang cukup signifikan antara berbagai kelompok muslim di Indonesia. Ada yang memaknakan bid'ah sebagai perbuatan apapun yang tidak pernah dicontohkan oleh Rasulullah dalam hal ibadah. ${ }^{16}$ Ada pula yang menilai bid'ah lebih terkhusus pada amalan tertentu dengan membagi bid'ah menjadi dua, yaitu bid'ah hasanah dan bid'ah dholalah. ${ }^{17}$ Pemaknaan ini menunjuk pada pola yang sama dengan pemaknaan kata kafir, yaitu ada yang memaknakan secara luas, dan ada yang memaknakan secara sempit (parsial).

Pada kata Jihad, juga nampak terjadi perbedaan pendapat seputar makna jihad secara terminologi teologis. Secara etimologi, jihad merupakan bentuk mashdar dari kata jahada, yang berarti bersungguh-

16 Almanhaj.or.id. Pengertian Bid'ah, Macam-Macam Bid'ah Dan Hukum-Hukumnya. Via, https://almanhaj.or.id/. Akses tanggal 3 Mei 2019

17 Nu.online.com. Inilah Kriteria Bid'ah Dhalalah dan Bid'ah Hasanah. Via, http://www.nu.or.id/post/read/67714/. Akses tanggal 2 Mei 2019 
sungguh. Dalam Kamus Besar Bahasa Indonesia Jihad memiliki makna antara lain berperang dan berjuang. ${ }^{18}$ Sebagian kalangan memaknai jihad secara ketat, yaitu berperang melawan kaum kafir. Terminologi ini selalu muncul dalam momentum tertentu umat Islam. Belakangan di Indonesia, kata jihad banyak digunakan dalam pesta demokrasi Pilpres. Masih segar dalam ingatan, salah satu kelompok pendukung calon presiden menggunakan istilah jihad dalam proses pemenangan calon mereka.

Di saat sebagian orang memaknakan kata jihad secara ketat, beberapa kalangan tetap menggunakan kata jihad dalam porsi yang lebih luas. Misalnya dengan menyebut pelajar sebagai mujahid, yaitu orang yang melakukan jihad. Menurut kelompok tersebut, jihad bisa memiliki berbagai bentuk, tidak hanya tentang berperang. Mengajar bisa saja merupakan upaya jihad, bekerja untuk kebutuhan keluarga, serta berbagai pekerjaan lain yang berorientasi kemuliaan. ${ }^{19}$ Gambaran perbedaan konseptual seputar makna jihad ini bisa direkam dalam penelusuran di internet. Dari situs bbc.com, diperoleh eterangan bahwa konsep jihad masih menjadi motif beberapa kalangan melakukan terorisme. Mereka meyakini

\footnotetext{
${ }^{18}$ Kamus Besar Bahasa Indonesia.

19 Vanny El Rahman. 5 Makna Jihad Menurut Santri, Gak Ada Satupun Diartikan Perang. Via, https://www.idntimes.com/news/indonesia/vannyrahman/. Akses tanggal 3 Mei 2019
}

bahwa jihad adalah upaya membunuh orang-orang yang tidak beriman kepada Allah. ${ }^{20}$ Hal ini juga sejalan dengan beberapa pengakuan mantan teroris yang bisa disaksikan di situs youtube.com. ${ }^{21}$ Dari keterangan tersebut sebagian muslim masih memaknai jihad secara parsial dan ekslusif. Adapun kata selanjutnya adalah ulama'. Pemaknaan masyarakat muslim belakangan ini (terutama saat proses pemilihan presiden beberapa waktu yang lalu) ulama' mengalami pendefinisian yang nampak menyempit. Beberapa kelompok mengkhususkan penyebutan ulama' hanya untuk kelompok mereka semata. Artinya, ulama' yang secara etimologi memiliki makna orang-orang yang mengetahui, tetapi dalam konteks kepentingan mereka, makna ulama' hanya pada orang-orang yang sejalan dengan mereka. Hal ini nampak dari beberapa kegiatan yang menggunakan istilah ulama' seperti ijtima' ulama'.

Beberapa kalangan menilai penggunaan istilah ijtima' ulama merupakan bentuk pengkotak-kotakan ulama. ${ }^{22}$ Kemudian sering pula didengungkan saat masa kampanye, "pilihlah presiden yang didu-

20 bbc.com. Jihad, khilafah, dan Konsep Lain yang Banyak Digunakan Menanamkan Bibit Intoleransi. Via, https://www.bbc.com/indonesia/trensosial-44136149 akses tanggal 12 Mei 2019

${ }^{21}$ Pengakuan Mantan Teroris. Via, https://www.youtube.com/watch?v=_8RLLgtCHCY akses tanggal 5 april 2019

Liputan6. Ijtima Ulama. Via. https://www.liputan6.com/tag/ijtima-ulama. Akses tanggal 5 Mei 2019 
kung ulama". Kalimat tesebut banyak didengungkan pelaku media sosial yang mendasarkan argumentasi mereka pada Ijtima Ulama Keduayang mendukung salah satu pasangan calon.Hal ini menjadi kontras ketika melihat realitas bahwa calon sebelah juga didukung oleh beberapa orang yang layak disebut ulama'. Dengan demikian terjadi upaya penyempitan semantik atas sebuah kata yang digunakan.Kata ulama' dinegasikan hanya pada sekelompok orang berdasar pilihan politik semata. Negasi inilah yang kemudian memperuncing konflik sosial keagamaan yang masih terasa hingga saat ini.

\section{Negasi semantik dalam memaknai}

\section{bahasa}

Dari uraian perihal pola pemahaman beberapa kelompok muslim terhadap katakata Arab berorientasi keagamaan, dapat dilihat suatu penyederhanaan semantik terhadap sebuah kata. Hal ini kemudian melahirkan negasi terhadap makna kata tersebut. Dari kata kafir, beberapa kalangan senantiasa ngotot untuk menentang keputusan Munas NU, tetapi mereka tidak mau terbuka dengan argumentasi pemaknaan bahasa yang ditawarkan pihak NU. Beberapa orang yang menentang statemen tersebut selalu merujuk kepada ayat maupun hadits dalam menegaskan makna kafir. Adanya sikap bersikukuh untuk mempertahankan pemaknaan mereka terhadap sebuah kata secara tidak langsung telah mengantarkan perdebatan tersebut pada batasan yang tak berujug.

Dalam tinjauan filsafat bahasa, khususnya dalam kerangka teoritis permainan bahasa 'language games' sebuah kata tidak bisa difinalkan dalam bentuk tertentu dengan makna yang mengikat. Bahasa memiliki sifat dasar dinamis. ${ }^{23}$ Artinya bahasa tidak bisa difinalkan dalam konteks tuturan dan wacana. Apa yang nampak dari fenomena berbahasa sebagaian kalangan diatasmenunjukkan pada konsep pemaknaan bahasa yang kaku. Dengan kata lain pemaknaan bahasa yang digunakan oleh kelompok-kelompok tersebut mengambil bentuk konsep linguistik klasik dimana bahasa diikat dalam dua struktur yang saling mengunci yaitu penandadan petanda. Derrida menilai konsep linguistik klasik merupakan upaya mengekang makna. ${ }^{24}$ Oleh karena itu, beberapa pemikir sesudah Ferdinand melakukan inovasi-inovasi yang dibutuhkan dalam konsep bahasa guna mengalternasi bentuk tuturan yang semakin kompleks.

Mengacu pada konsep permainan bahasa, terjadi pengekangan semantik oleh sebagian kalangan yang terlibat dalam pemaknaan bahasa di muka. Apa yang

${ }^{23}$ Abdul Chaer. Linguistik Umum (Jakarta: PT. Rineka Cipta, 2012). Hlm, 53

24 Christopher Norris. Deconsturction Theory And Practice. (London: Rottledge, 2002), hlm. 24-25 
seharusnya dipahami dari sebuah bahasa dipotong secara sistematis melalui konstruksi pemahaman bahasa mereka. Hal ini tentu akan berdampak sangat fatal terutama dalam konteks dialog keagamaan yang membutuhkan kesalingterbukaan dan saling memahami apa yang dipahami oleh masingmasing pelaku dialog. ${ }^{25}$

Bisa dilihat beberapa contoh dialog yang menumbuhkan negasi semantik ini dalam penyajian pendapat di media massa. Pada kolom tulisan di Tempo.co.id misalnya, ketika membaca artikel tentang konsep non-muslim yang menjadi tawaran NU dalam melihat orang-orang di luar Islam yang secara teologis disebut kafir. Mereka yangmembaca artikel tentang hasil Munas tersebut, menyerang argumentasi dengan mengedepankan dalil-dalil teologis baik dari ayat Al-Quran maupun hadits nabi. Mereka dengan nada yang sedikit marah menegaskan argumentasinya dan secara sepihak menyalahkan organisasi NU. "NU sudah mulai mau mengamandemen Al-Quran. Mereka sudah mensejajarkan al-Quran dengan Undang-Undang buatan manusia." "26, "istilah kafir itu adalah istilah yang sudah ada dalam al-Quran maupun hadits,

\footnotetext{
25 Mujib dan Rumahuru. Paradigma Transpormatif Masyarakat Dialog. (Yogyakarta, Pustaka Pelajar, 2010), hlm. 47

26 Tempo.co. 5 Hasil Munas Alim Ulama NU: Soal Sebutan Kafir sampai Bisnis MLM. Via, https://nasional.tempo.co/read/1181081/.Akses tanggal 10 Mei 2019
}

ngapain dirubah-rubah?",27 demikian pula berbagai komentar serupa yang menunjukkan pada negasi semantik yang cukup sempit.

Negasi semantik inilah yang kemudian melahirkan sikap ekslusif dalam berdialog dan bertindak, baik dalam konteks teologis maupun sosiologis. Perlu kiranya dilakukan pendidikan semantik bagi para tokoh keagamaan agar mampu memahami bahasa secara lebih luas dan terbuka. Bersikap ekslusif pada pemahaman sendiri dan menutup mata pada apa yang dipahami oleh orang lain akan melahirkan patologipatologi yang bukan hanya terkait dengan materi dialogis semata tetapi konstruksi keragaman sosial keagamaan bangsa yang sudah menjadi warisan negeri ini.

\section{Beberapa Faktor yang Melahirkan}

\section{Negasi Semantik}

Ada beberapa faktor yang melahirkan fenomena negasi semantik tersebut. Berdasar pada penelusuran peneliti pada beberapa artikel ataupun komentar beberapa kelompok tentang istilah-istilah keagamaan tersebut, bahwa minimnya pemahaman tentang konsep dasar linguitik menjadi salah satu faktor yang melahirkan negasi semantik tersebut. Hal ini dilihat dari beberapa komentar yang mencoba memberikan analisis seputar istilah tersebut secara linguis-

${ }^{27}$ Ini bentuk salah satu komentar netizen yang peneliti jaring di media sosial Facebook. Akses tanggal 5 Mei 2019 
tik. Ketika mengomentari kembali komentar tersebut, selalu orang yang sebelumnya menolak konsep tersebut bersikeras untuk tidak menerima argumentasi tersebut. Bahkan cara pandang semacam itu (yang menggunakan pendekatan linguistik) dianggap sesat.

Kedua, kuatnya nalar bayani yang dimiliki oleh beberapa kelompok muslim yang berseberangan, atau yang memaknai isitlah tersebut secara tekstual. Menurut mereka, apa yang sudah disebutkan dalam al-Quran ataupun hadits nabi harus diikuti secara kaffah dan tidak boleh memberikan argumentasi yang menentang. Pemahaman secara tekstual (terpaku pada teks) tersebut membuat beberapa argumentasi yang bersifat rasional selalu mental dihadapan mereka. Memang, pola nalar bayani ini sebagaimana yang disinggung oleh Al-Jabiri memiliki kekuatan hafalan yang mumpuni sehingga merasa total dalam melihat teks. Bagi mereka apa yang tertulis dalam teks harus diikuti seperti apa adanya. ${ }^{28}$

Menurut kelompok yang kedua ini, rasionalitas tidak berlaku dihadapan teks kitab suci maupun hadits nabi. Itulah yang kemudian membuat mereka menolak argumentasi orang-orang yang menggunakan logikanya karena metode maupun hasil analisinya bertentangan dengan prinsip yang

\footnotetext{
${ }^{28}$ Muhammad Abeed Al-Jabiri. Bunyatul Aqlil Aroby. (Beirut: Markaz Diroosatul Wahdah alArobiyah, 2009), hlm.20
}

mereka yakini. Dengan demikian, nalar bayani yang diwarisi oleh sebagian kaum muslimin di negeri ini menjadi salah satu faktor penting lahirnya kelompok-kelompok yang tidak bisa menerima pendapat orang lain secara terbuka.

Ketiga, ada warisan teologis yang cukup kental dalam tradisi beberapa kelompok muslim di Indonesia. Warisan tersebut sering kali bersifat otoritatif, bahkan menyamai kitab suci. Misalnya apa yang mereka baca dari kita-kitab pemimpin mereka, tidak boleh disanggah karena imam itu maksum dari dosa. Apa yang ditulis dalam kitabnya harus diikuti. Jika kitab pemimpin mereka saja telah sampai pada derajat semacam itu, maka ketika dihadapan al-Quran maupun hadits, semuanya sudah bersifat final.

\section{Mengaplikasikan Model Pemahaman}

\section{Semantik-Pragmatikpluralistik}

Melihat fenomena pemahaman bahasa sebagian kalangan tersebut, maka dirasa perlu untuk menghadirkan pola pemahaman bahasa yang lebih terbuka dalam melihat suatu wacana keagamaan. Mengacu pada konsep permainan bahasa, maka dalam memaknai bahasa dibuthkan pemaknaan bahasa yang menekankan pada konteks tuturan. Untuk mampu memberikan makna yang proporsional dalam sebuah tuturan maka perlu untuk memberikan kesempatan untuk setiap bahasa men- 
jangkau segala bidang medan semantiknya. Dengan kata lain, setiap melihat tuturan perlu untuk disikapi dengan memberikan seluruh alternatif medan makna yang mungkin tepat dari sebuah kata. Misalnya kata kafir, dalam konteks dialog keagamaan, perlu dihadirkan dalam kajian linguistik yang lebih mendalam, serta kajian semantik yang plural. Artinya, pemaknaan terhadap kata kafir tersebut, tidak boleh terbatas hanya pada makna yang diberikan oleh kelompok mereka secara ekslusif, tetapi harus dihadirkan dalam dialektika medan makna yang ditampung aspek semantiknya.

Demikian pula kata-kata yang lain seperti bid'ah. Secara semantik kata tersebut memiliki medan makna yang memungkinkan untuk dihadirkan. Seperti bid'ah yang berarti inovasi. Sebagaimana yang bisa ditelusuri dalam berbagai kamus Arab, bid'un memiliki beberapa medan makna yang bisa dihuni oleh referensi tertentu. Artinya, bid'ah tidak serta merta merujuk pada satu makna, yaitu suatu konsep tentang sesuatu yang tidak pernah dilakukan oleh Rasulullah.

Sejalan dengan model pemaknaan tersebut, M Quraisy Shihab menguraikan tiga hakikat makna lafazh, yaitu: hakikat lughowiyah (pengertian kebahasaan), hakikat 'urfiyah (pengertian sehari-hari) dan hakikat syar'iyyah (makna yang digunakan oleh bahasa syariat/agama). ${ }^{29}$ Ketiga hakikat makna tersebut memiliki lokus tersendiri dalam tradisi tutur. Dalam menegaskan makna kita harus melihat kesesuaian konteks dalam menggunakan hakikat makna lafaz. Dengan demikian dibutuhkan proses seleksi medan semantik untuk menuju sebuah kesimpulan. Konsep pemaknaan bahasa yang digunakan juga harus melewati dialog makna untuk mendapatkan kesesuaian antara teks dan makna teks tersebut.

Berkaca dari berbagai fenomena yang digambarkan pada pembahasan sebelumnya, dibutuhkan model pemahaman bahasa yang tidak hanya melihat makna kata secara mengikat pada makna tertentu tetapi juga harus dibebaskan untuk menemui makna yang sesuai dan yang dikehendaki. Disinilah esensi konsep language games dapat ditarik dalam analisa pembahasan ini. Ketika melihat sebuah tuturan atau argumentasi maka perlu dilihat konteks tuturan (how to use) bukan semata berhenti pada apa maknanya (what the mean). Ketika kita mampu melihat pola permainan bahasa terutama dalam hubungan kata ke medan makna (semantik) maka membangun dialog yang inklusif tidak akan mengalami hambatan yang berarti.

Memahami bahwa bahasa memiliki sisi kompleksitas yang tinggi, maka dalam

${ }^{29}$ M. Quraisy Shihab. Kaidah Tafsir Syarat, Ketentuan, dan Aturan yang Patut Anda Ketahui dalam Memahami Ayat-Ayat Al-Quran. (Tangerang: Penerbit Lentera Hati,2015), hlm. 114 
memaknai bahasa proses negosiasi semantik-pragmatik mutlak dibutuhkan. Semantik yang dipahami sebagai ilmu yang mempelajari tentang makna yang lahir dari sebuah bahasa dan pragmatik yang merupakan ilmu yang membahas tentang konstruksi makna karena aspek diluar bahasa (konteks), maka dirasa perlu untuk membangun suatu konsep pemahaman bahasa yang terbangun dari dua landasan linguistik tersebut.

Charles Sander Piece, memberikan alternatif model pemahaman bahasa dengan menawarkan konsep pragmatic pluralism (pluralisme pragmatik). Menurut teori tersebut, suatu bahasa dipahami tidak dalam maknanya yang terpendam dalam bahasa, tetapi pada kebiasaan penggunaannya (meaning as habit). ${ }^{30}$ Konsep ini pada prinsipnya sejalan dengan teori language games yang ditawarkan Ludwig Wittgenstein, hanya memiliki beberapa perluasan konseptual. Dari kajian literasi seputar teori filsafat bahasa tersebut, dapat dikemukakan model pemaknaan bahasa yang berbasi semantik-pragmatik pluralistik. Model ini menawarkan model pemaknaan bahasa yang memberikan segala kemungkinan makna atas sebuah kata. Tidak ada makna yang final untuk menuju hakekat makna yang seungguhnya.

30 Sandra B. Rosenthal. Charles Peirce's Pragmatic Pluralism., hlm. 41
Pola pemaknaan semantik-pragmatik pluralistik ini kemudian sangat dibutuhkan dalam membagun sebuah dialog, terutama dalam konteks dialog keagamaan. Telah banyak contoh yang menunjukkan betapa posisi bahasa dalam upaya rekonsiliasi dialogis sangatlah vital. Oleh karena itu memahami bahasa tentu harus secara pluralistik dengan mempertimbangan segala aspek yang ada di dalam bahasa, baik semantik, pragmatik maupun konteks tuturannya.

\section{Kesimpulan}

Dari paparan di atas dapat disimpulkan bahwa konstruksi pemaknaan bahasa berorientasi keagamaan beberapa kelompok muslim di Indonesia mengalami negasi semantik. Artinya ada pemaknaan secara parsial terhadap kata-kata yang berorientasi keagamaan. Negasi semantik tersebut disebabkan oleh beberapa faktor, yaitu, lemahnya pemahaman beberapa kelompok tersebut terhadap konsep linguistik, adanya pola pikir bayani yang membuat mereka terpaku pada teks, serta adanya sakaralisasi konsep yang diwariskan dari para pendahulu mereka. Sebagai refleksi dari uraian yang dibuat, maka perlu dihadirkan pola pemaknaan bahasa yang lebih pluralistik dengan melibatkan aspek semantik, pragmatik serta konteks tuturan. Ketika setiap kelompok mampu memhami bahasa secara plural, maka upaya membangun dialog 
dalam konteks keagamaan maupun keyakinan akan bisa dilaksanakan dengan baik. Adanya sikap menerima dengan terbuka konsep kelompok lain dalam memaknai istilah-istilah keagamaannya akan menghadirkan kehidupan beragama yang toleran dan damai.

\section{Daftar Pustaka}

Aljabiri. M Abeed. Bunyatul Aqlil Aroby Dirosah Tahliliyah Naqdiyah li Nazhmil Ma'rifah fi Ats-Tsaqofatil Arobiyah. Beirut: Markaz Diroosaatil Wahdatil Arobiyah, 2009

B. Rosenthal, Sandra. Charles Peirce's Pragmatic Pluralism. New York: State University of New York Press, 1994

Chair, Abdul.Linguistik Umum. 2012. Jakarta: PT. Rineka Cipta

Hidayat, Asep Muhammad. Filsafat Bahasa, Mengungkap Hakikat Bahasa, Makna dan Tanda. 2014. Bandung: Rosda Karya

Huberman dan Milles, 'Manajememen Data dan Metode Analisis', dalam Denzim dan Lincoln, Handbook of Qualitative Research, Terj. Darisyanto dkk.Yogyakarta: Pustaka Pelajar, 2009

https://nasional.tempo.co/read/1181081/

http://www.nu.or.id/post/read/103253/ https://almanhaj.or.id/

http://www.nu.or.id/post/read/67714/ https://www.idntimes.com/news/indonesia/v anny-rahman/

https://www.bbc.com/indonesia/trensosial$\underline{44136149}$

https://www.youtube.com/watch? $\mathrm{v}=8 \mathrm{RLL}$ $\mathrm{gtCHCY}$

https://www.liputan6.com/tag/ijtima-ulama.

https://nasional.tempo.co/read/1181081/.

Lav, Daniel. Radical Islam and The Revival of Medieval Theology. 2012. New York: Cambridge University.

Muhammad. Metode Penelitian Bahasa. 2014. Yogyakarta: Arruz Media.

Mujib dan Romahuru. Paradigma Transformatif Masyarakat Dialog Membangun Fondasi Dialog Agama-Agama Berbasis Teologi Humanis. Yogyakarta: Pustaka Pelajar, 2010

Mustansyir, Rizal. Filsafat Analitik; Sejarah, Perkembangan dan Peranan Para Tokohnya. 2007. Yogyakarta: Pustaka Pelajar

Norris, Christopher. Deconsturction Theory And Practice. London: Rottledge, 2002.

Shihab. M Quraish. Kaidah Tafsir Syarat, Ketentuan, dan Aturan yang Patut Anda Ketahui dalam Memahami Ayat-Ayat Al-Quran. Tangerang: Penerbit Lentera Hati, 2015

Tim Penyusun Kamus Pusat Pembinaan dan Pengembangan Bahasa, Kamus Besar Bahasa Indonesia, Jakarta: Balai Pustaka, 1995 
78 | II-Fathin Vol. 2,Edisi 1 Januari-Juni 2019

Wittgenstein, Ludwig. Philosophical Investigation. 1986. London: Great Britanian

Williams, Meredith. Wittgenstein, Mind and Meaning, Towards A Social Conception of Mind. 1999. London: Routledge. 